\title{
LAPAROSCOPIC VERSUS OPEN SPLENECTOMY IN THE MANAGEMENT OF HEMATOLOGIC DISEASES
}

\author{
Manuela V. Sapucahy, Joel Faintuch, Cláudio J.C. Bresciani, Pedro L. Bertevello, \\ Angelita Habr-Gama and Joaquim José Gama-Rodrigues
}

SAPUCAHY MV et al. - Laparoscopic versus open splenectomy in the management of hematologic diseases. Rev. Hosp.

Clín. Fac. Med. S. Paulo 58 (5):243-249, 2003.

Splenectomy is the best available treatment for severe forms of hereditary spherocytosis, idiopathic thrombocytopenic purpura, and other hematologic conditions when these prove refractory to conservative management. It has been employed for many decades with low mortality and favorable remission rates.

The use of laparoscopic splenectomy in recent years has been rapidly and even enthusiastically adopted in this field. However, the exact role of laparoscopic versus open surgery for hematologic diseases is still debated. In this study of 58 adult patients, laparoscopic procedures were compared with conventional splenectomies for similar indications.

METHODS: All patients were operated on within an 8-year period. Subjects underwent similar procedures under the supervision of the same surgical school and were compared regarding age, gender, body mass index, and diagnosis. Laparoscopically managed cases (Group I, $\mathrm{n}=30$ ) were prospectively followed according to a written protocol, whereas the same investigation was retrospectively done with regard to traditional laparotomy (Group II, $\mathrm{n}=28$ ).

Methods included general and demographic findings, duration and technical steps of operation, blood loss, weight of spleen, need for conversion (in minimally invasive subjects), intraoperative and postoperative complications, time until realimentation, postoperative hospitalization, mortality, and late follow-up including recurrence rate.

RESULTS: Idiopathic thrombocytopenic purpura was the surgical indication in over $50 \%$ of the patients in both groups, but familial spherocytosis, thalassemia, myelodysplasia, and lymphomas were also represented in this series. Laparoscopic procedures took more time to perform $(P=0.004)$, and postoperative hospitalization was 2 days shorter, but this difference was not statistically significant. Postoperative hematocrit and volume of blood transfusions was equivalent, although the laparoscopic cases had a somewhat lower preoperative hematocrit (NS) and displayed better recovery for this measurement $(P=0.03)$. More patients in Group I were able to accept oral food on the first day than subjects undergoing conventional operations $(P<0.05)$. Relatively few conversions were necessary during the minimally invasive surgeries $(13.3 \%)$, and postoperative early and late complications as well as recurrences occurred in similar proportions. Also, the mean weight of the spleen was not statistically different between the groups, although there was a marked numerical tendency toward larger masses in conventional procedures. No spleen in Group I exceeded $2.0 \mathrm{~kg}$, whereas in Group II values up to $4.0 \mathrm{~kg}$ occurred, and the mean weight was $50 \%$ higher in the latter group.

CONCLUSIONS: 1) Minimally invasive splenectomy was essentially comparable to open surgery with regard to safety, efficacy, and late results; 2) Advantages concerning shorter postoperative hospitalization could not be shown, despite earlier food intake and a non-significant tendency toward earlier discharge; 3 ) This new modality should be considered an option in cases of hematologic conditions whenever the spleen is not hugely enlarged.

DESCRIPTORS: Splenectomy. Laparoscopic operation. Hereditary spherocytosis. Idiopathic thrombocytopenic purpura. Hematologic disease.

Modern laparoscopic surgery was introduced by Mouret who, in 1987, removed a diseased gallbladder in Lyon, France employing the instruments of a fellow gynecologist ${ }^{1}$. A few months later Dubois ${ }^{2,3}$ in Paris not
From the Division of Surgery of the Digestive Tract, Department of Gastroenterology, Hospital das Clínicas, Faculty of Medicine, University of São Paulo - São Paulo/SP, Brazil.

Received for publication on December 02, 2002. only announced his own laparoscopic cholecystectomy, but also the establishment of a systematic training program with laboratory animals, which was soon emulated in other parts of the world. Within just a few more years, a 
whole new specialty would be announced, with video-laparoscopy, special instruments, insufflators and light sources, and successful followers in virtually all continents ${ }^{4}$.

The advantages of reduced trauma, less postoperative pain, earlier hospital discharge, and superior esthetic results were not overlooked by other surgical branches, and soon the laparoscopic method found supporters in urology, pediatric surgery, thoracic and cardiovascular surgery, plastic surgery, endocrinologic surgery, bariatric surgery, orthopedics, and other areas.

Within the abdomen, not only hollow viscera but also solid organs were approached by this minimally invasive method, and the spleen was not to be an exception. As early as in 1993, authors such as Flowers ${ }^{5}$ and Lefor et al. ${ }^{6,7}$ were applying the new technique for benign and malignant splenic conditions.

Since the spleen is the major site for blood cell destruction both in physiologic and pathologic circumstances, splenectomy has been proved useful for severe aplastic, autoimmune, and cryptogenic anemia; thrombocytopenia or neutropenia; hypersplenism; bone marrow dysfunction; and miscellaneous hematologic diseases that do not adequately respond to pharmacological management ${ }^{8}$. These include congenital spherocytosis, idiopathic thrombocytopenic purpura, autoimmune hemolytic anemia, major thalassemia, idiopathic neutropenia, myelodysplasia, hypersplenism, Hodgkin's lymphoma, Gaucher's disease, and splenic sarcoidosis ${ }^{5-9}$.

In spite of multiple potential indications, the initial experience with laparoscopic splenectomy was usually focused on idiopathic thrombocytopenic purpura because the spleen is not considerably enlarged in this circumstance?.

Indeed, voluminous spleens may pose a challenge to minimally invasive procedures because of increased chances of hemorrhage and need for conversion to the open approach. These challenges stem from technical difficulties in dissecting enlarged splenic vessels, intrinsic bleeding tendencies linked to low thrombocyte counts, or possible coagulation factor deficits, and occsional focal infarctions that produce adhesions and anatomical distortions. Nevertheless, well-trained teams have demonstrated the feasibility of removing even massive organs when the technique is carefully employed ${ }^{10}$.

Of course, laparoscopic splenectomy may be used for trauma, cysts, aneurisms of the splenic artery, benign or malignant tumors, and other nonhematologic situations. Experience with small children is also growing, but these are out of the scope of this study ${ }^{11}$.

The current series aims to retrospectively compare indications, results, and complications of laparoscopic splenectomy exclusively in adolescents and adults suffering from hematologic diseases, employing as controls a similar population undergoing open surgery within an 8-year period (November 1993 to June 2001).

\section{PATIENTS AND METHODS}

Clinical charts from 3 hospitals ( $\mathrm{n}=$ 120) were reviewed for criteria of inclusion and exclusion, of which 58 were adequate. All patients had been operated on in accordance with the principles and routines and under the supervision of our Division, and most of the laparoscopic procedures were performed by the first author (67\%).

\section{Criteria for inclusion:}

Age $>13$ years, males or females

Confirmed hematologic diagnosis

Unresponsive to pharmacological

therapy

Elective procedure

\section{Criteria for exclusion:}

Splenectomy for portal hypertension Splenectomy during gastric cancer surgery

Splenectomy due to trauma or other nonhematologic diseases

Re-operations because of accessory spleen

Procedures carried out by external teams

Surgical technique: Laparoscopic operations employed 4 (70\% of the patients) or 5 trocars (30.0\% of the group) via the transperitoneal route (Fig. 1), and as soon as the gastrocolic ligament was opened, preliminary ligature of the splenic artery was carried out. A plastic bag was employed to protect the abdominal cavity from implants, to permit cutting or slicing of larger organs and to enable the surgeon to easily and safely retrieve the splenic mass.

Open splenectomy was equally performed via the peritoneal cavity adopting the initial ligature of the splenic artery. Vascular ligatures and dissections were done from the lower pole upwards, after the omental cavity was exposed. In both modalities, accessory spleens were carefully located and removed, and external drainage was an option, depending on the local conditions.

Methods: Variables included clinical and demographic information, surgical findings (operative time and need for blood transfusions, weight of the spleen, drainage and other technical maneuvers), time to postoperative food intake, preoperative and postoperative hematologic profile, immediate and late complications, and recurrence of the disease.

Stratification: Patients were divided into Laparoscopic (Group I, $\mathrm{n}=30$ ) and Conventional (Group II, $\mathrm{n}=$ 28) populations, according to the performed procedure. 


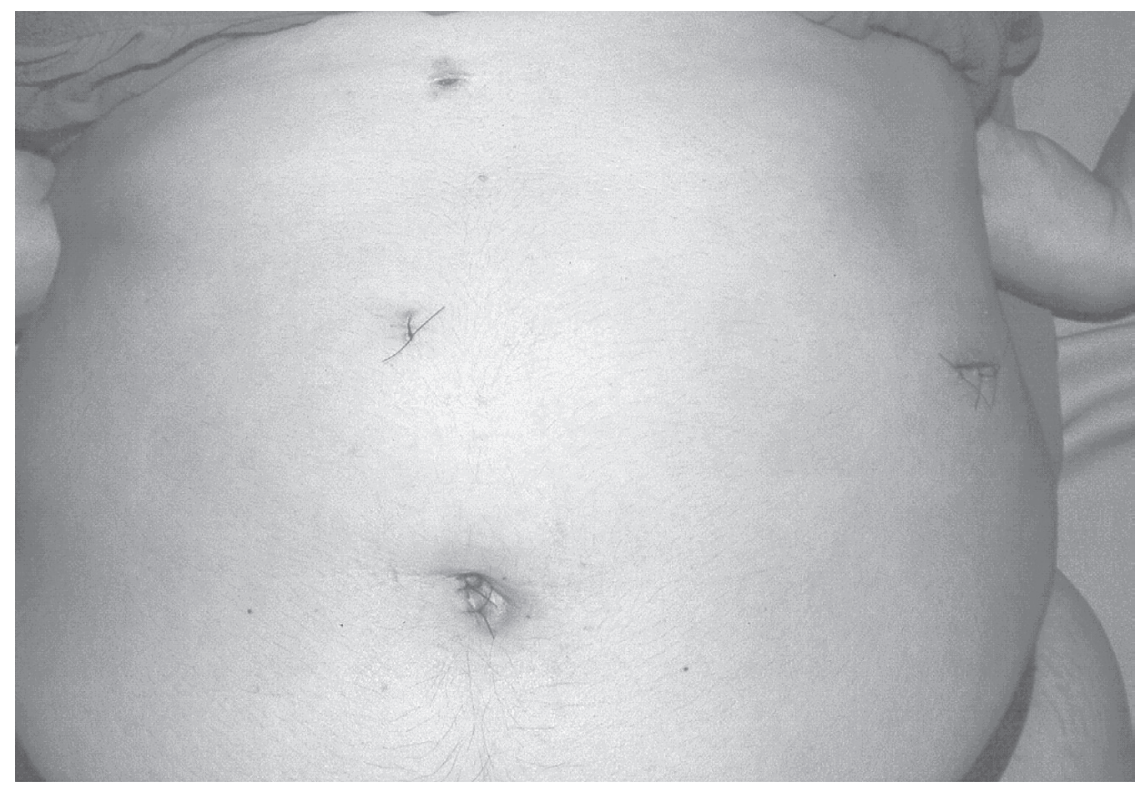

Figure 1 - Trocar placement for laparoscopic splenectomy: (1) a 10-mm camera port at the umbilicus; (2) a 5-mm working port half way between the umbilicus and the xiphoid process in the midline; (3) a 5-mm hepatic retractor port at the xiphoid process; (4) a 12-mm port site was enlarged to $2 \mathrm{~cm}$ and used as the extraction incision to remove spleen.

Randomization: No randomization could be applied, since this was a basically retrospective study and all operations had been performed already.

Statistical analysis: Discrete measurements were compared by means of a chi-square analysis and Fisher's exact test, whereas quantitative variables were first submitted to variance and normality assessment using Levene as well as Kolmogorov-Smirnov tests. Actual differences were estimated by Student's $t$ test or Mann-Whitney test as appropriate. A significance limit of $5 \%(P<0.05)$ was adopted.

Preliminary findings: The age in both groups was similar ( $40.6 \pm 18.5$ vs. $38.6 \pm 17.5$, NS), females were the majority in both contexts (19/30 vs. 20/28, NS), and body mass index was comparable $\left(24.8 \pm 3.2\right.$ vs. $25.7 \pm 5.2 \mathrm{~kg} / \mathrm{m}^{2}$, NS). Idiopathic thrombocytopenic purpura was the most common entity in both groups (17/30 vs. 17/28, NS), followed by familial spherocytosis, hemolytic anemia, myelodysplasia, lymphoma, and miscellaneous conditions.
In addition to splenectomy, hepatic biopsy (3/30 vs. $6 / 28$, NS) and cholecystectomy (5/30 vs. $6 / 28$, NS) were simultaneously performed in this series. All patients received antipneumococcus vaccine in the preoperative period.

\section{RESULTS}

Laparoscopic procedures took longer than standard splenectomy (261 \pm 83 vs. $184 \pm 71$ minutes, $P=$ $0.0004)$. Hospital stay was numerically shorter in Group I $(5.1 \pm 2.4$ vs. $7.1 \pm$ 8.1 days), but statistical confirmation was not obtained. In a few cases, preliminary ligature of the splenic artery was not performed by the surgeon (8/ 30 vs. $3 / 28, \mathrm{NS}$ ), whereas drains were more often utilized in the minimally invasive procedure than in open surgery $(15 / 30$ vs. $4 / 28, P=0.009)$.

The mean weight of the spleen was $40 \%$ smaller in Group I than II (478 \pm 489 vs. $789 \pm 1072 \mathrm{~g}$ ), and maximum weight was also quite different (2000 vs. $3980 \mathrm{~g}$ ), but statistical difference could not be demonstrated. On the other hand, the laparoscopic route was as efficient as the conventional approach for identifying and eliminating accessory spleens (5/30 vs. 2/28, NS).

In 4 patients, conversion to open surgery was required (13.3\%). Two of these were secondary to persistent hemorrhage; a third case had firm adhesions between the spleen and the diaphragm due to previous infarction and displayed heart arrhythmia whenever maneuvers to free the organ were attempted; and 1 subject exhibited strongly adherent and confluent lymph nodes and areas of fibrosis surrounding the hilar vessels of the spleen, thus preventing dissection of this area by the laparoscopic method.

The most frequent intraoperative complication in both groups was bleeding, and comparable numbers of patients in both populations required blood transfusions (12/30 vs. $7 / 28$, NS). Minor laceration of the stomach was seen in an open case, and was immediately repaired, and a minor skin burn due to leak of current from the laparoscopic cautery was identified in Group I, without differences in total intraoperative complications between the populations ( $8 / 30$ vs. $2 / 28$, NS). Again, early postoperative (up to hospital discharge) and late complications occurred in equivalent proportions (respectively $7 / 30$ vs. $12 / 28$, NS and $3 /$ 30 vs. $7 / 28$, NS).

Serious early complications in Group I were represented by 1 episode of bleeding through the drain that required re-operation and 1 death on the 2nd postoperative day in a 63 yearold-male due to necroscopically confirmed myocardial infarction. In Group II subjects, 3 re-operations were necessary, 1 due to bleeding with hemorrhagic shock, another connected to a subphrenic abscess, and the last one because of abdominal dehiscence and evisceration.

Significant late complications in a 
laparoscopically managed patient included 1 wound abscess that was drained on the outpatient visit, and 3 incisional hernias occurred in cases managed by conventional surgery.

The laparoscopic procedure permitted earlier food intake by the patients (77\% accepted food on the first postoperative day, versus $43 \%$ in the control group, $P=0.05)$. Also recovery of hematocrit values was more effective in the laparoscopic group $(P=0.033)$, whereas no differences were observed in platelet counts. Within the average follow-up period of 2 years, hematologic recurrences were uncommon in both groups (4/30 vs. $3 / 28, \mathrm{NS})$.

\section{DISCUSSION}

Not many new concepts in medicine are truly paradigmatic, and few have been recognized as more practical in recent years than the laparoscopic method of performing surgery. Laparoscopic surgery clearly passes the test of great innovations, which is the criterion of before and after. Indeed, few people would question that modern surgical treatment can be classified as before and after the advent of laparoscopic procedures.

This change was surely record-setting regarding elapsed time between first attempts and definitive international acceptance. No more than a couple of years separated the pioneering reports of the French precursors ${ }^{1,2}$ and the widespread adoption of the technique by multiple specialties and countless services and countries. With regard to laparoscopic splenectomy, a similar phenomenon occurred: the first 2 reports appeared between 1991 and $1992^{12,13}$, and in $1998^{14}$ the new modality was already praised as the "gold standard" for surgical management of the spleen in benign hematologic diseases whenever the organ is not much enlarged.
In spite of the enthusiasm of the authors mentioned above $\mathrm{e}^{14}$, this is a complex subject, and it is likely that for some years to come the optimal alternative for performing splenectomy in certain circumstances will still be debated.

Baccarani et al. ${ }^{15}$ reviewed 104 papers published between 1989 and 1998, many of which compared open versus laparoscopic splenectomy. Interestingly, none of the studies was prospective, with most of them using nonrandomized controls as in the present experience. Among these investigations, 41 fulfilled the criteria of inclusion, representing over 600 laparoscopic splenectomies. The principal advantages of the new option were earlier restoration of gastrointestinal function and shorter hospital stay.

Klingler et al. ${ }^{16}$ attempted a similar collective review of 21 reports, of which 6 were comparative. Nevertheless, definitive conclusions were hard to come by, since the size of the spleen was not homogeneous among laparoscopic and conventional groups. Similarly to the current investigation, most surgeons preferred the open approach for very large spleens and laparoscopic route for smaller ones.

In the present protocol, great care was directed toward homogenization of the 2 series, and they were certainly comparable with regard to biodemographic features, hematologic diagnosis, and general surgical management. A limit in size of a laparoscopically removable spleen was not adopted, as suggested by Poulin \& Thibault ${ }^{17}$, namely of up to $20 \mathrm{~cm}$ length or $1 \mathrm{~kg}$. These precautions notwithstanding, a tendency toward clustering of the bigger spleens in Group II occurred, with greater amounts of preoperative thrombocytopenia in this population.

Surgical maneuvers and allied care were as similar as possible for the 2 modalities, including general technique, vaccine use, preliminary liga- ture of the splenic artery, and blood transfusions. However, a discrepancy was noted with regard to drainage, which was more frequent in the laparoscopic group.

Operative time was expected to be longer for the laparoscopic approach, and that was really the case. A few words are required to explain the actual duration numbers, which exceeded those published in other series ${ }^{15,16}$ for both open and minimally invasive routes. The longer duration times were surely due to the participation in all operations of junior residents, as well as to the fact that several of the laparoscopic procedures were done at a time when this technique was still new in the service, thus coinciding with the learning curve of the hospital team.

No clear pattern was noted concerning the amount of blood loss or volume of transfusions required, and interpretation of these values are clouded anyway by circumstances such as size of the spleen, technical difficulties during operation, and the baseline coagulation status of the patient. In accordance with a number of authors ${ }^{18-20}$, no differences were detected between the groups. It is worthwhile to emphasize that hematocrit values recovered more effectively after laparoscopy, thus suggesting less operative hemorrhage than in the open modality.

General morbidity and mortality are usually reported as worse when laparotomy instead of laparoscopy is utilized $^{19-21}$, but statistical confirmation is not always achieved. In the current series, no statistical difference could be demonstrated when these variables were examined. One highly relevant pitfall is the need for conversion to open surgery, and in this experience, conversion was required in $13.3 \%$ of the operations. That is a larger proportion than has been reported by some authors ${ }^{16}$ but is perfectly compatible with some other reports ${ }^{18,19,22}$. 
Several of these investigations indicate both earlier refeeding and earlier hospital discharge when laparoscopic resection is provided ${ }^{16,18,19}$, but in the current study, only the former advantage was evident. It is expected that minimally invasive surgery should elicit a more modest neuroendocrine response and also less postoperative ileus, thus explaining rapid restoration of gastrointestinal function, and this was clearly the case in this series. On the other hand, postoperative hospitalization is usually linked to general morbidity. Since morbidity was equivalent in both situations, the same outcome should be anticipated for time until discharge.

Accessory spleens and recurrences failed to display any differences between the groups. These are potentially important findings, since videolaparoscopy has been suspected as less effective in the search and identification of accessory spleens ${ }^{16}$. Unrecognized splenic tissue is a cause for concern and may explain early recurrence of the hematologic disease, but fortu- nately, all analyzed procedures were equally successful in this regard.

Since the first laparoscopic splenectomy performed in Brazil in 199323, few reports have been published in this country ${ }^{24-27}$. However, a questionnaire was submitted to practicing laparoscopists by the Brazilian Society of Laparoscopic Surgery ${ }^{28}$ polling the results of 408 procedures. Yet it is difficult to compare our results with these findings, since they were not systematic investigations, and the questionnaire was responded to by a nonrepresentative sample of Brazilian professionals.

In any case, they bear witness to the growing interest in this modality and to the rapid increase in the number of laparoscopic splenectomies performed in this country. It is not unreasonable to foresee that technical obstacles that were listed here will progressively diminish in the future, thus rendering video-laparoscopy an even more appealing option in the treatment of chronic hematologic diseases.

\section{CONCLUSIONS}

1) Laparoscopic procedures were indicated for smaller spleens with less affected platelet counts;

2) Hematocrit recovery suggested less blood loss during video-laparoscopy, although these operations took longer to perform;

3) Laparoscopically managed patients accepted food earlier, but morbidity, mortality, and duration of hospitalization were similar in both groups;

4) Laparoscopic procedures were as effective as open procedures in the removal of accessory spleens and prevention of postoperative recurrence;

5) Conversion to laparotomy was required in $13 \%$ of the laparoscopic procedures; however, the final outcome of the patients was not adversely affected by this change;

6) It can be affirmed that the laparoscopic splenectomy is a valid and safe option for the treatment of chronic hematologic conditions whenever the spleen is not massively enlarged.

\section{RESUMO}

SAPUCAHY MV e col. - Esplenectomia laparoscópica versus aberta no tratamento de doenças hematológicas. Rev. Hosp. Clín. Fac. Med. S. Paulo 58 (5):243-249, 2003.

A esplenectomia é o melhor tratamento disponível para formas graves de esferocitose hereditária, púrpura trombocitopênica idiopática e outras entidades hematológicas refratárias à abordagem conservadora. Ela tem sido empregada há muitas décadas com baixa mortalidade e taxas de remissão favoráveis.

A alternativa de esplenectomia laparoscópica em anos recentes foi adotada rapidamente e até entusiasti- camente, todavia o papel exato das intervenções abertas em contraposição às laparoscópicas para doenças hematológicas ainda é objeto de debate. Num estudo de 58 pacientes adultos, os procedimentos laparoscópicos foram comparados com as esplenectomias convencionais em indicações semelhantes.

MÉTODOS: Todos os pacientes foram operados num período de 8 anos. Eles foram submetidos a operações análogas sob a supervisão da mesma escola cirúrgica e eram comparáveis no tocante a idade, sexo, índice de massa corporal e diagnóstico. Os casos abordados laparoscopicamente (Grupo I, $\mathrm{n}=30$ ) foram seguidos prospectivamente de acordo com protocolo escrito, ao passo que a mesma investigação foi aplicada retrospectivamente no que concerne aos doentes de esplenectomia aberta (Grupo II, $\mathrm{n}=$ 28).

Os métodos incluíram achados gerais e demográficos, duração e passos técnicos da cirurgia, perda sangüínea, peso do baço, necessidade de conversão (nos casos minimamente invasivos), complicações intra e pós-operatórias, tempo para realimentação, hospitalização pós-operatória, mortalidade e seguimento tardio, incluindo recidivas.

RESULTADOS: A púrpura trombocitopênica idiopática foi a indicação cirúrgica em mais de $50 \%$ dos enfermos de ambos os grupos, entretanto esferocitose familiar, talassemia, 
mielodisplasia e linfomas também estavam representados nesta série. As intervenções laparoscópicas demoraram mais $(\mathrm{p}=0,004)$ e sua hospitalização pós-operatória foi dois dias mais breve, porém esta diferença não foi estatisticamente significativa. O hematócrito pós-operatório e o volume de transfusões foram equivalentes, no entanto os casos laparoscópicos exibiam um hematócrito pré-operatório ligeiramente inferior (NS) e a recuperação desta variável foi melhor $(\mathrm{p}=0,03)$.

Mais pacientes do Grupo I toleraram dieta oral no primeiro dia que casos abordados convencionalmente $(\mathrm{p}<0,05)$. Relativamente poucas con- versões foram necessárias no decurso das laparoscopias (13,3\%), e as complicações pós-operatórias precoces e tardias assim como as recidivas distribuíram-se de forma equiitativa. Também não foi possível demonstrar-se diferenças no peso do baço, ainda que no Grupo I nenhum órgão excedesse a $2,0 \mathrm{~kg}$, sendo que no Grupo II este valor chegou até $4,0 \mathrm{~kg}$, notando-se ainda que o peso médio foi $50 \%$ mais elevado nesta última população.

CONCLUSÕES: 1) A esplenectomia minimamente invasiva foi essencialmente comparável à variante aberta no tocante à segurança, eficácia e resultados tardios; 2) Não foi possível comprovar-se vantagens relativas à menor hospitalização pós-operatória, embora a realimentação fosse mais precoce e houvesse uma tendência nãosignificativa para alta hospitalar antecipada; 3) Esta nova modalidade deve ser considerada uma excelente opção para casos de moléstias hematológicas sempre que o baço não estiver fortemente aumentado.

DESCRITORES: Esplenectomia. Operação laparoscópica. Esferocitose hereditária. Púrpura trombocitopênica idiopática. Doença hematológica.

\section{REFERENCES}

1. MOURET P - From the first laparoscopic cholecystectomy to the frontiers of laparoscopic surgery: the future perspectives. Dig Surg 1991; 8:124.

2. DUBOIS F, BERTHELOT G, LEVARD H - Cholécystectomie par coelioscopie. Presse Med 1989; 18:980-982.

3. DUBOIS F, ICARD P, BERTHELOT G et al. - Coelioscopic cholecystectomy. Preliminary report of 36 cases. Ann Surg 1990; 211:60-62.

4. FILIPI CJ, FITZGIBBONS JR, SALERNO GM - Historical review: diagnostic laparoscopic cholecystectomy and beyond. In: ZUCKER KA - Surgical Laparoscopy. St. Louis, Missouri, Quality Medical Publishing, 1991. p. 3-21.

5. FLOWERS JL - Laparoscopic splenectomy. In: ZUCKER KA Surgical Laparoscopy Update. $2^{\text {nd }}$ ed. St. Louis, Missouri, Quality Medical Publishing, 1993. p. 357-371.

6. LEFOR AT, FLOWERS JL, HEYMAN MR - Laparoscopic staging of Hodgkin's disease. Surg Oncol 1993; 2(3):217-220.

7. LEFOR AT, MELVIN WS, BAILEY RW et al. - Laparoscopic splenectomy in the management of immune thrombocytopenia purpura. Surgery $1993 ; \mathbf{1 1 4}(3): 613-618$.

8. KATKHOUDA N, MAVOR E - Laparoscopic splenectomy. Surg Clin North Am 2000; 80(4):1285-1297.

9. FRIEDMAN RL, FALLAS MJ, CARROLL BJ et al. - Laparoscopic splenectomy for ITP. The gold standard. Surg Endosc 1996; 10(10):991-995.

10. TARGARONA EM, ESPERT JJ, BALAGUE C et al. Splenomegaly should not be considered a contraindication for laparoscopic splenectomy. Ann Surg 1998; 228(1):35-41
11. GIGOT JF, DE VILLE DE GOYET J, VAN BEERS BE et al. Laparoscopic splenectomy in adults and children: experience with 31 patients. Surgery 1996; 119(4):384-389.

12. DELAITRE B, MAIGNIEN B - Splenectomy by the coelioscopic approach. Report of a case [Letter]. Presse Med 1991; 20:2263.

13. CARROLL BJ, PHILLIPS EH, SEMEL CJ et al. - Laparoscopic splenectomy. Surg Endosc 1992; 6(4):183-185.

14. GIGOT JF, LENGELE B, GIANELLO P et al. - Present status of laparoscopic splenectomy for hematologic diseases: certitudes and unresolved issues. Semin Laparosc Surg 1998; 5(3):147167.

15. BACCARANI U, DONINI A, TERROSU G et al. - Laparoscopic splenectomy for haematological diseases: review of current concepts and opinions. Eur J Surg 1999; 165(10):917-923.

16. KLINGLER PJ, TSIOTOS GG, GLASER KS et al. - Laparoscopic splenectomy: evolution and current status. Surg Laparosc Endose 1999; 9(1):1-8.

17. POULIN EC, THIBAULT C - Laparoscopic splenectomy for massive splenomegaly: operative technique and case report. Can J Surg 1995; 38(1):69-72.

18. REGE RV, MERRIAM LT, JOEHL RJ - Laparoscopic splenectomy. Surg Clin North Am 1996; 76(3):459-468.

19. GLASGOW RE, YEE LF, MULVIHILL SJ - Laparoscopic splenectomy: the emerging standard. Surg Endosc 1997; 11:108-112.

20. KUSMINSKY RE, BOLAND JP, TILEY EH et al. - Hand-assisted laparoscopic splenectomy. Surg Laparosc Endosc 1995; 5(6):463-467. 
21. TARGARONA EM, ESPERT JJ, BOMBUY E et al. - Complications of laparoscopic splenectomy. Arch Surg 2000; 135(10):11371140 .

22. DELAITRE B, CHAMPAULT G, BARRAT C et al. - Laparoscopic splenectomy for hematologic diseases. Study of 275 cases. French Society of Laparoscopic Surgery. Ann Chir 2000; 125(6):522-529.

23. GAMA-RODRIGUES JJ, BRESCIANI CJC - Esplenectomia associada à colecistectomia e exploração das vias biliares pelo método vídeo-laparoscópico. [Vídeo-livre apresentado no I Seminário Nacional de Cirurgia Laparoscópica da Sociedade Brasileira de Cirurgia Laparoscópica-SOBRACIL]. Porto Alegre / RS, de 22 à 24 de abril de 1993.

24. NOGUEIRA MVF, HIDD BE, SABOYA SOBRINHO CJ et al. Esplenectomia laparoscópica. Rev Col Bras Cir 1994; 21(5):278-281.
25. NOGUEIRA MVF, AZEVEDO JCS, TEIXEIRA CAB et al. Terceira esplenectomia para recidiva de púrpura trombocitopênica imunológica por vídeolaparoscopia. Rev Cirurg Vídeoendoscópica 1995; 2(1):32-35.

26. MARTINS FP, RESENDE AP, GUERRA FILHO V et al. Esplenectomia laparoscópica. Rev Cient SOBRACIL 1998; 2:19-23.

27. BRANDALISE NA, ARANHA NC - A esplenectomia e a colecistectomia por vídeo-laparoscopia no tratamento da esferocitose congênita. Rev Cient SOBRACIL 1998; 3:1-5.

28. NOGUEIRA MVF et al. - Inquérito Nacional sobre Esplenectomia Laparoscópica. [Conferência proferida durante o V Congresso Brasileiro de Vídeo-cirurgia da SOBRACIL (Sociedade Brasileira de Vídeo-cirurgia), Rio de Janeiro, 2001]. 